\title{
Development of Probiotic Beverage from Whey and Pineapple Juice
}

\author{
Manasi Shukla1, Yogesh Kumar Jha ${ }^{1,2 *}$ and Shemelis Admassu
}

${ }^{1}$ Department of Food Science and Technology, Govind Ballabh Pant University of Agriculture and Technology, Pantnagar, Uttarakhand 263145, India

${ }^{2}$ Food Engineering Graduate Program me, School of Chemical and Bio-Engineering, Addis Ababa Institute of Technology, Addis Ababa University, Ethiopia

\begin{abstract}
The aim of this study was to develop a probiotic beverage using whey and pineapple juice. Lactobacillus acidophilus was used as the probiotic organism. The level of pineapple juice addition was optimized on the basis of sensory quality evaluation. Fermentation time using 1 per cent inoculum of $L$. acidophilus was optimized on the basis of sensory quality evaluation, growth and activity in terms of $\mathrm{pH}$ and acidity. The 65:35 blend ratio of whey and pineapple juice fermented for $5 \mathrm{hr}$ gave desirable results with highest sensory scores for overall acceptability and a total viable count of more than $10^{6} \mathrm{cfu}^{\mathrm{ml} \mathrm{l}^{-1}}$.
\end{abstract}

Keywords: Whey; Probiotic beverage; Pineapple whey beverage; Sensory quality; Storage stability

\section{Introduction}

The loss of body fluids from exertion, temperature or age gives rise to thirst, which is offset by drinking. The fluids lost are also accompanied by a loss of electrolytes, vitamins, lactates, amino acids and other organic components. A whey drink can replace much of the lost organics and in organics to the extracellular fluid. Whey, which is so rapidly assimilable, forms an ideal metabolic substrate. Whey is a genuine thirst quencher, unlike most soft drinks. Whey drinks are light and refreshing but less acidic than fruit juices [1]. The medicinal and nutritive value of sweet and acidic whey can be utilized with fruit juices/ pulp and concentrates in developing acceptable long life beverages which appear to be the most obvious and logical avenue for utilizing the nutrients of whey into the human food chain. The manufacture of whey-based beverages requires the mixing of appropriate fruit juices and minimally processed whey with selection of suitable stabilizers and acidulants to develop acceptable whey based fruit beverages [2]. Recently, the key growth sector in utilization of whey has been Probiotic drinks. In addition to their role in fermentation processes, some probiotic lactic acid bacteria have been studied as dietary sources of live microorganisms destined to promote a positive impact in the host by improving the properties of the indigenous beneficial micro biota [3]. Documented benefits of the ingestion of probiotics include: reduction of serum cholesterol, alleviation of lactose intolerance, reduction of cancer risk, resistance to enteric pathogens, among others [4]. Based on these facts, the present investigation was conducted to develop a probiotic beverage from whey and pineapple juice and to study its storage stability.

\section{Materials and Methods}

\section{Material collection and sample preparation}

Skim milk was procured from Student's Dairy Plant, Department of Food Science \& Technology, G.B. Pant University of Agriculture and technology, Pantnagar. Pineapple fruits (Variety Queen) were procured from a local market in Pantnagar. The freeze dried culture of Lactobacillus acidophilus NCDC-015 was obtained from Culture Collection Centre, National Dairy Research Institute, Karnal (Haryana). Skim milk was heated in a stainless steel vessel to $95^{\circ} \mathrm{C}$ followed by cooling to $70^{\circ} \mathrm{C}$. The hot milk was acidified by adding two per cent citric acid solution followed by continuous stirring which resulted in the complete coagulation of the milk protein (casein). The liquid (whey) was filtered using muslin cloth. The prepared whey was heated to $85^{\circ} \mathrm{C}$ before blending with fruit juice. Pineapples were de-crowned and peeled followed by cutting into small pieces. The fruit pieces were grinded in a mixer and the resulting pulp was passed through a double layered muslin cloth to extract the juice. The freeze dried culture was activated using a 3 percent (w/v) Litmus milk solution. The culture was maintained bi-weekly transfers and stored at $5 \pm 1^{\circ} \mathrm{C}$.

\section{Probiotic beverage process}

The combination of whey and pineapple juice was optimized by preparing a beverage with different levels of pineapple juice and subjecting to sensory evaluation by a trained sensory panels using a 9 point hedonic scale for color, consistency, flavor and overall acceptability. The various blends of whey-pineapple juice prepared using a constant sugar level of $10 \%$ were $80 \mathrm{w}: 20 \mathrm{P}, 75 \mathrm{w}: 25 \mathrm{P}, 70 \mathrm{w}: 30 \mathrm{P}$ and $65 \mathrm{w}: 35 \mathrm{P}$. The blend that was rated best after sensory evaluation was selected for acidification with Lactobacillus acidophilus. The incubation period was optimized by inoculating whey with $1 \%$ inoculum of Lactobacillus acidophilus with or without the addition of pineapple juice. The beverage was evaluated for sensory characteristics, total viable count, $\mathrm{pH}$ and titratable acidity for samples fermented for 5, 10, 15, 20 and $24 \mathrm{~h}$. For storage stability, the optimized beverage samples were stored at $5 \pm 1^{\circ} \mathrm{C}$ and $30 \pm 1^{\circ} \mathrm{C}$. Changes in sensory characteristics, total viable counts, $\mathrm{pH}$ and titratable acidity were studied during storage.

\section{Analytical methods}

Chemical and microbiological methods: Total soluble solids was measured using a hand refractometer of $0-32^{\circ} \mathrm{B}$ (ERMA make). The $\mathrm{pH}$ of the beverages was determined using the digital $\mathrm{pH}$ meter (Model No. 5633, Electronics Corporation of India Ltd., Hyderabad). Titratable acidity was determined according to the AOAC [5] method. Reducing sugar, Non reducing sugar and total sugars were determined by the

*Corresponding author: Yogesh Kumar Jha, Department of Food Science and Technology, Govind Ballabh Pant University of Agriculture and Technology, Pantnagar, Uttarakhand 263145, India, E-mail: Jhayk1697@rediffmail.com

Received October 02, 2012; Accepted November 16, 2012; Published November 26, 2012

Citation: Shukla M, Jha YK, Admassu S (2013) Development of Probiotic Beverage from Whey and Pineapple Juice. J Food Process Technol 4: 206 doi:10.4172/2157-7110.1000206

Copyright: ( 2013 Shukla M, et al. This is an open-access article distributed under the terms of the Creative Commons Attribution License, which permits unrestricted use, distribution, and reproduction in any medium, provided the original author and source are credited. 
method described by Ranganna [6]. Ash content and Moisture were determined according to the AOAC [5] methods. Protein estimation was done by Micro-Kjeldahl method [5]. Viable counts in the samples were determined according to A.P.H.A.[7] procedure using lactic agar [8].

Bio-chemical, microbiological and sensory quality evaluation of beverage during storage: The beverage samples prepared from an optimized 65:35 blend of whey and pineapple juice with addition of $10 \%$ sugar was fermented for $5 \mathrm{hrs}$ using a $1 \%$ inoculum of Lactobacillus acidophilus. The beverage samples so obtained were stored at refrigeration temperature $\left(5 \pm 1^{\circ} \mathrm{C}\right)$ and ambient temperature $\left(30 \pm 1^{\circ} \mathrm{C}\right)$ and analyzed for biochemical, microbiological and sensory attributes at an interval of $4 \mathrm{~d}$ and $24 \mathrm{hrs}$, respectively.

\section{Statistical analysis}

Statistical procedures as described by Snedecor and Cochran [9] were used to analyze the data for the interpretation of results. Mean, standard deviation and analysis of variance (ANOVA) were used to describe the results.

\section{Sensory quality evaluation}

The beverage samples were evaluated as described by Larmond [10] for their sensory characteristics namely color and appearance, taste and flavor, body or consistency and overall acceptability by a trained panels comprising of 25 panelists drawn from faculty members and post graduate students of the Department. The panelists were asked to record their observations on the sensory sheet based on a 9 point hedonic scale ( 9 and 1 points showing like extremely and dislike extremely).

\section{Results and Discussion}

\section{Proximate analysis}

The total solids in whey, pine apple juice and Probiotic whey based pine apple beverage were $6.40,12.79$ and $12.80 \%$, respectively whereas titratable acidity was $0.18,0.87$ and $0.546 \%$ lactic acid. Probiotic beverage $(65 \mathrm{w}: 35 \mathrm{P})$ had $0.546 \%$ acidity, protein $(0.23 \%)$, ash $(0.51 \%)$, total soluble solids $(12.2 \mathrm{~B})$, reducing sugars $(1.48 \%)$ and non reducing sugars $(9.96 \%)$ respectively.

\section{Optimization of pineapple juice level in whey for beverage preparation}

Whey and pineapple juice were blended in four different proportions i.e. 80:20, 75:25, 70:30 and 65:35 and evaluated for sensory attributes namely color and appearance, consistency, flavor and overall acceptability. The highest score for flavor, consistency, color and appearance was given to the beverage containing pineapple juice and whey in the ratio of 35:65.The mean scores of this blend for color and appearance, consistency, flavor and overall acceptability were 7.93 , $7.81,8.37$ and 8.93 respectively. Therefore, the $65 \mathrm{w}: 35 \mathrm{P}$ blend of whey and pineapple juice was chosen for the further course of investigation. The blend $(65 \mathrm{w}: 35 \mathrm{P})$ differed significantly $(\mathrm{P}<0.05)$ and rated best among others blends (Table1)

\section{Optimization of growth conditions for Lactobacillus acidophilus in probiotic beverage development}

Variations in fermentation time and medium were studied in terms of Overall acceptability of the beverage, total viable counts, $\mathrm{pH}$ and titratable acidity. Whey supplemented with $10 \%$ sucrose was fermented for different time intervals with or without the addition of pineapple juice. The effect of Lactobacillus acidophilus on sensory attributes of whey with or without pineapple juice during fermentation has been shown in table 2. Color and appearance of the beverage was significantly $(\mathrm{P} \leq 0.05)$ affected by the incubation period. The mean scores for color and appearance ranged from 8.83 to 5.99 for whey and from 8.92 to 6.53 for whey with pineapple juice. The mean score was highest (8.92) for whey fermented along with pineapple juice for $5 \mathrm{~h}$. The sensory scores for consistency reduced significantly $(\mathrm{P} \leq 0.05)$ with increase in fermentation time for both whey and whey-pineapple juice blend. The sensory score for consistency of fermented whey ranged from

\begin{tabular}{|l|l|l|l|l|}
\hline Whey : pineapple ratio & Color and appearance & Consistency & Flavor & Overall acceptability \\
\hline $80: 20$ & $6.31^{\mathrm{C}}$ & $6.37^{\mathrm{C}}$ & $6.18^{\mathrm{D}}$ & $6.18^{\mathrm{D}}$ \\
\hline $75: 25$ & $6.93^{\mathrm{B}}$ & $6.87^{\mathrm{B}}$ & $6.75^{\mathrm{C}}$ \\
\hline $70: 30$ & $7.18^{\mathrm{B}}$ & $7.25^{\mathrm{A}, \mathrm{B}}$ & $6.93^{\mathrm{C}}$ \\
\hline $65: 35$ & $7.93^{\mathrm{A}}$ & $7.81^{\mathrm{A}}$ & $7.37^{\mathrm{B}}$ \\
\hline S.E.M. & 0.187 & 0.185 & $8.37^{\mathrm{B}}$ \\
\hline CD at $5 \%$ & 0.543 & 0.537 & $8.93^{\mathrm{A}}$ \\
\hline
\end{tabular}

*Average of four trials

${ }^{1}$ Means followed by different letters (A, B, C, D) as superscripts in a column differ significantly at $5 \%$ level

Table 1: Effect of different blends of whey and pineapple juice on the sensory characteristics of the beverage*

\begin{tabular}{|c|c|c|c|c|c|c|c|c|}
\hline \multirow[b]{2}{*}{ Fermentation time (h) } & \multicolumn{2}{|c|}{ Color and Appearance } & \multicolumn{2}{|c|}{ Consistency } & \multicolumn{2}{|l|}{ Flavor } & \multicolumn{2}{|c|}{ Overall acceptability } \\
\hline & Whey & $\begin{array}{l}\text { Whey-pine-apple } \\
\text { juice blend }(65: 35)\end{array}$ & Whey & $\begin{array}{l}\text { Whey-pine-apple } \\
\text { juice blend }(65: 35)\end{array}$ & Whey & $\begin{array}{l}\text { Whey-pine-apple } \\
\text { juice blend }(65: 35)\end{array}$ & Whey & $\begin{array}{l}\text { Whey-pine-apple } \\
\text { juice blend }(65: 35)\end{array}$ \\
\hline 5 & 8.83 & 8.92 & 8.74 & 8.69 & 8.58 & 8.88 & 8.65 & 8.87 \\
\hline 10 & 8.63 & 8.39 & 8.29 & 8.21 & 8.33 & 8.42 & 8.26 & 8.3 \\
\hline 15 & 8.08 & 8.07 & 8.09 & 8.03 & 7.88 & 7.16 & 7.92 & 7.57 \\
\hline 20 & 7.48 & 7.90 & 6.36 & 7.62 & 6.52 & 5.87 & 7.00 & 6.41 \\
\hline \multirow[t]{2}{*}{24} & 5.99 & 6.53 & 5.76 & 6.04 & 4.34 & 4.39 & 4.82 & 4.99 \\
\hline & S.E.M & CD at $5 \%$ & S.E.M & CD at $5 \%$ & S.E.M & CD at $5 \%$ & S.E.M & CD at $5 \%$ \\
\hline Medium (A) & 0.035 & 0.099 & 0.03 & 0.086 & 0.045 & 0.129 & 0.044 & 0.124 \\
\hline Fermentation time (B) & 0.055 & 0.156 & 0.048 & 0.136 & 0.072 & 0.204 & 0.069 & 0.196 \\
\hline$A \times B$ & 0.078 & 0.221 & 0.068 & 0.193 & 0.102 & 0.288 & 0.098 & 0.277 \\
\hline
\end{tabular}

Table 2: Effect of Lactobacillus acidophilus on sensory characteristics of whey with and without pineapple juice at $37 \pm 1{ }^{\circ} \mathrm{C}$. 
8.74 to 5.76 . The sensory scores for consistency of fermented wheypineapple juice blend ranged from 8.69 to 6.04 . The sensory scores for flavor ranged from 8.58 to 4.34 for whey fermented alone and from 8.88 to 4.39 for fermented whey-pineapple juice blend. The mean score for flavor decreased significantly with increasing fermentation time irrespective of the medium. The mean score for overall acceptability ranged from 8.87 to 4.99 in case of whey-pineapple juice blend and 8.65 to 4.82 in case of whey fermented alone. Highest score for overall acceptability was seen in case of whey-pineapple juice blend fermented for $5 \mathrm{~h}$.

\section{Enumeration of total viable counts}

The viable counts were assessed after 5, 10, 15, 20 and $24 \mathrm{~h}$ of incubation at $37^{\circ} \mathrm{C}$. It was observed that whey with pineapple juice gave higher viable counts $\left(4.7 \times 10^{7} \mathrm{cfu} \cdot \mathrm{ml}^{-1}\right)$ up to $10 \mathrm{~h}$ of fermentation. But after $15 \mathrm{~h}$, the whey fermented alone, gave higher viable counts ranging from $6.89 \times 10^{8}$ to $9.69 \times 10^{8} \mathrm{cfu} / \mathrm{ml}$. Both whey and whey-pineapple juice blend attained a total viable count of more than $10^{6} \mathrm{cfu} / \mathrm{ml}$ within five $\mathrm{h}$ of fermentation (Table 3 ). The total viable count increased significantly with increase in fermentation time from 5 to $24 \mathrm{~h}$. The total viable count for whey ranged from $2.21 \times 10^{7}$ to $9.69 \times 10^{8} \mathrm{cfu} / \mathrm{ml}$. Whey-pineapple juice blend showed higher counts during initial stages of fermentation ranging from $3.78 \times 10^{7}$ to $8.38 \times 10^{8} \mathrm{cfu} / \mathrm{ml}$.

\section{Effect of probiotic on $\mathrm{pH}$ and titratable acidity}

Table 4 shows the effect of incubation period on the $\mathrm{pH}$ of whey and whey-pineapple juice blend. $\mathrm{pH}$ of the samples reduced significantly $(\mathrm{P}<0.05)$ with increasing fermentation time for both whey and wheypineapple juice blend. The mean value of $\mathrm{pH}$ obtained in case of whey fermented alone ranged from 4.82-3.30. The mean value of $\mathrm{pH}$ obtained in case of whey-pineapple juice blend ranged from 4.36-3.87. Higher viable counts during the initial period of fermentation resulted in comparative lowering of $\mathrm{pH}$ for whey fermented along with pineapple juice. But, after $15 \mathrm{~h}$ of fermentation, $\mathrm{pH}$ was significantly lowered for whey fermented alone. Table 4 shows the effect of incubation period on the titratable acidity of whey with or without pineapple juice. Titratable acidity increased significantly $(\mathrm{P} \leq 0.05)$ with increasing fermentation time irrespective of the medium. The mean values obtained for whey ranged from 0.394 to 1.353 . The mean values obtained for wheypineapple juice blend ranged from 0.546 to 0.926 . Whey-pineapple juice blend gave higher titratable acidity for 5 and $10 \mathrm{~h}$ of fermentation whereas there was a significant increase in the titratable acidity for whey fermented alone after $15 \mathrm{~h}$ of incubation. The commercial probiotic beverage should possess a minimum viable count of $10^{6} \mathrm{cfu} / \mathrm{ml}$ [11] and should also have an acceptable flavor.

Keeping in view these aspects, experiments were carried out to appraise the suitability of whey with or without the addition of pineapple juice as a growth medium for Lactobacillus acidophilus for the preparation of probiotic beverage. It was observed that whey fermented along with pineapple juice for $5 \mathrm{~h}$ gave the highest scores for overall acceptability (8.76) as compared to whey fermented alone. The scores for overall acceptability gradually declined with increasing fermentation time irrespective of the medium. Table 4 shows that the $\mathrm{pH}$ and titratable acidity affect the flavor profile of a beverage. In the present study, it was observed that whey-pineapple blend having a $\mathrm{pH}$ of 4.36 and titratable acidity of $0.546 \%$ gave the best flavor profile to the probiotic beverage. These observations exhibited an acceptable beverage by fermenting a blend of whey and pineapple juice (65:35) for a period of $5 \mathrm{hrs}$. The prepared product had desired health benefits due to the probiotic organisms.

\begin{tabular}{|l|l|l|l|}
\hline Fermentation time (h) & \multicolumn{2}{|l|}{ Medium } \\
\cline { 2 - 3 } & Whey & Whey-pineapple juice blend (65:35) \\
\hline 5 & $2.21 \times 10^{7}$ & $3.78 \times 10^{7}$ \\
\hline 10 & $3.5 \times 10^{7}$ & $4.71 \times 10^{7}$ \\
\hline 15 & $6.89 \times 10^{8}$ & $5.20 \times 10^{8}$ \\
\hline 20 & $9.20 \times 10^{8}$ & $7.78 \times 10^{8}$ & \\
\hline 24 & $9.69 \times 10^{8}$ & $8.38 \times 10^{8}$ & $\mathrm{~A} \times \mathrm{B}$ \\
\hline & Medium (A) & Fermentation time (B) & $6.94 \times 10^{4}$ \\
\hline S.E.M. & $3.10 \times 10^{4}$ & $4.91 \times 10^{4}$ & $2.04 \times 10^{5}$ \\
\hline CD at 5\% & $9.16 \times 10^{4}$ & $1.44 \times 10^{5}$ & \\
\hline
\end{tabular}

* Incubation temperature: $37 \pm 1^{\circ} \mathrm{C}$

Table 3: Effect of fermentation period on the total viable count of whey with and without pineapple juice*

\begin{tabular}{|c|c|c|c|c|c|}
\hline \multirow{2}{*}{$\begin{array}{l}\text { Fermentation } \\
\text { time (h) }\end{array}$} & \multicolumn{5}{|c|}{ Medium } \\
\hline & $\begin{array}{l}\text { Whey } \\
\text { pH }\end{array}$ & T.A\% & \multicolumn{3}{|c|}{$\begin{array}{l}\text { Whey-pineapple juice blend (65w:35P) } \\
\text { pH }\end{array}$} \\
\hline 5 & 4.82 & 0.394 & 4.36 & \multicolumn{2}{|l|}{0.546} \\
\hline 10 & 4.42 & 0.511 & 4.32 & \multicolumn{2}{|l|}{0.605} \\
\hline 15 & 4.00 & 1.077 & 4.20 & \multicolumn{2}{|l|}{0.806} \\
\hline 20 & 3.61 & 1.265 & 3.78 & \multicolumn{2}{|c|}{0.896} \\
\hline \multirow[t]{2}{*}{24} & 3.30 & 1.353 & 3.87 & \multicolumn{2}{|c|}{0.926} \\
\hline & \multicolumn{2}{|c|}{ Medium (A) } & \multicolumn{2}{|c|}{ Fermentation time $(\mathrm{B})$} & $A \times B$ \\
\hline S.E.M. & 0.0207 & 0.00043 & 0.032 & & 0.0668 \\
\hline $\mathrm{CD}$ at $5 \%$ & 0.0612 & 0.0127 & 0.096 & & 0.0201 \\
\hline
\end{tabular}

* Incubation temperature: $37 \pm 1{ }^{\circ} \mathrm{C}$

Table 4: Effect of fermentation period on the $\mathrm{pH}$ and titratable acidity of whey with and without pineapple juice*

\section{Sensory characteristics of probiotic beverage during storage}

The changes in sensory attributes of the probiotic beverage have been shown in table 5 for refrigerated and ambient storage temperatures. The whey based probiotic beverage did not show sensory differences for the first two weeks at refrigerated storage. But after the second week, difference was perceived in color and flavor. According to a consensus made with the panelists during sensory evaluation, it was determined that the main descriptors that characterized the product were acidity and sweetness, with acidity being the attribute responsible for the sensory difference perceived by the panelists. Even though a slight acidification was detected by the sensory panels and agreed that the beverage was acceptable for a period of $24 \mathrm{~d}$ at $5 \pm 1^{\circ} \mathrm{C}$ and $48 \mathrm{hrs}$ at $30 \pm 1^{\circ} \mathrm{C}$. Srivastava et al. [12] developed a fermented whey beverage using a mixed culture of Lactobacillus acidophilus and Streptococcus thermophilus.

The $\mathrm{pH}$ of the fresh beverage prepared from whey and pineapple juice fermented for $5 \mathrm{hr}$ was 4.38 . The $\mathrm{pH}$ of the samples gradually declined after $12 \mathrm{~d}$ at refrigerated storage. The $\mathrm{pH}$ ranged from 4.38 to 3.98 after 28 days of storage. During storage of the samples at ambient temperature, $\mathrm{pH}$ lowered significantly $(\mathrm{P} \leq 0.05)$ after $48 \mathrm{hr}$ (Table 6). Kumar et al. [13] reported a decline in $\mathrm{pH}$ of whey based pineapple juice RTS after $90 \mathrm{~d}$ at refrigerated storage. Kumar et al. [14] showed that there was a gradual decline in $\mathrm{pH}$ of Soy milk and whey blended papaya RTS. Similar results were reported by Devi et al. [15], for whey based fruit beverages stored at refrigeration temp. The initial acidity of the fermented beverage prepared from whey and pineapple juice was $0.546 \%$. The acidity increased during the refrigerated storage from 0.546 to $0.89 \%$ after $28 \mathrm{~d}$. The increase in acidity was more prominent in case of storage at ambient temperature wherein the acidity reached $0.89 \%$ after $120 \mathrm{hr}$ of storage (Table 6). Reddy et al. [16] showed that that the titratable acidity values were significantly influenced by 
Citation: Shukla M, Jha YK, Admassu S (2013) Development of Probiotic Beverage from Whey and Pineapple Juice. J Food Process Technol 4: 206. doi:10.4172/2157-7110.1000206

Page 4 of 4

\begin{tabular}{|c|c|c|c|c|c|c|c|c|c|}
\hline$S P(d)$ at $5 \pm 1^{\circ} \mathrm{C}$ & C\&A & Con. & Flavor & OAA & $\mathrm{SP}(\mathrm{h})$ at $30 \pm 1^{\circ} \mathrm{C}$ & C\&A & Con. & Flavor & OAA \\
\hline 0 & $8.74^{a}$ & $8.80^{\mathrm{a}}$ & $8.82^{a}$ & $8.68^{a}$ & 0 & $8.40^{\mathrm{a}}$ & $7.75^{\mathrm{a}}$ & $8.75^{\mathrm{a}}$ & $8.40^{\mathrm{a}}$ \\
\hline 4 & $8.77^{\mathrm{a}}$ & $8.65^{a}$ & $8.82^{\mathrm{a}}$ & $8.68^{a}$ & 24 & $8.05^{a}$ & $7.55^{\mathrm{a}, \mathrm{b}}$ & $8.36^{a}$ & $7.90^{\mathrm{b}}$ \\
\hline 8 & $8.67^{a}$ & $8.30^{b, c}$ & $8.64^{a}$ & $8.63^{a}$ & 48 & $7.05^{b}$ & $7.22^{\mathrm{b}}$ & $6.85^{b}$ & $7.12^{\mathrm{c}}$ \\
\hline 12 & $8.71^{a}$ & $8.40^{b, c}$ & $8.68^{a}$ & $8.33^{b, c}$ & 72 & $6.34^{c}$ & $6.24^{c}$ & $5.84^{c}$ & $5.83^{d}$ \\
\hline 16 & $7.92^{\mathrm{b}}$ & $8.19^{c}$ & $8.26^{b}$ & $8.21^{\mathrm{c}}$ & 96 & $4.59^{d}$ & $4.44^{d}$ & $3.51^{d}$ & $4.09^{\mathrm{e}}$ \\
\hline 20 & $7.72^{\mathrm{c}}$ & $7.95^{\mathrm{d}, \mathrm{e}}$ & $7.69^{c}$ & $7.89^{d}$ & 120 & $4.17^{\mathrm{e}}$ & $3.62^{\mathrm{e}}$ & $3.04^{e}$ & $3.81^{\mathrm{f}}$ \\
\hline 24 & $7.11^{d}$ & $7.79^{\mathrm{e}}$ & $6.53^{d}$ & $6.89^{\mathrm{e}}$ & |------- & ------ & ----- & ------ & ----- \\
\hline 28 & $6.77^{\mathrm{e}}$ & $7.05^{f}$ & $5.73^{e}$ & $5.89^{f}$ & ------ & ---- & ---- & ----- & ----- \\
\hline S.E.M. & 0.060 & 0.078 & 0.067 & 0.057 & S.E.M & 0.131 & 0.116 & 0.154 & 0.110 \\
\hline CD at $5 \%$ & 0.169 & 0.220 & 0.190 & 0.163 & CD at $5 \%$ & 0.374 & 0.330 & 0.439 & 0.311 \\
\hline
\end{tabular}

${ }^{1}$ Means followed by different superscript as letters (a, b, c, d, e, f) in a column differ significantly at $5 \%$ level SP - Storage Period; C\&A - Color \& Appearance; Con. Consistency; OAA - Overall acceptability

Table 5: Changes in sensory characteristics ${ }^{1}$ of whey-pineapple (65:35) probiotic beverage during storage.

\begin{tabular}{|c|c|c|c|c|c|c|c|}
\hline $\begin{array}{l}\text { Storage period }(\mathrm{d}) \text { at } \\
5 \pm 1^{\circ} \mathrm{C}\end{array}$ & $\mathrm{pH}$ & $\begin{array}{l}\text { Total viable count } \\
\text { (cfu/ml) }\end{array}$ & $\begin{array}{l}\text { Titratable acidity } \\
\text { lactic acid) }\end{array}$ & $\begin{array}{l}\text { Storage period }(\mathrm{h}) \text { at } \\
30 \pm 1^{\circ} \mathrm{C}\end{array}$ & $\mathrm{pH}$ & $\begin{array}{l}\text { Total viable count } \\
\text { (cfu/ml) }\end{array}$ & $\begin{array}{l}\text { Titratable acidity (\% } \\
\text { lactic acid) }\end{array}$ \\
\hline 0 & 4.38 & $3.8 \times 10^{7}$ & 0.546 & 0 & 4.38 & $3.8 \times 10^{7}$ & 0.546 \\
\hline 4 & 4.37 & $2.9 \times 10^{7}$ & 0.56 & 24 & 4.34 & $8.2 \times 10^{8}$ & 0.59 \\
\hline 8 & 4.37 & $4.1 \times 10^{7}$ & 0.56 & 48 & 4.28 & $9.5 \times 10^{8}$ & 0.71 \\
\hline 12 & 4.35 & $3.6 \times 10^{7}$ & 0.58 & 72 & 4.19 & $5.6 \times 10^{7}$ & 0.80 \\
\hline 16 & 4.34 & $2.8 \times 10^{7}$ & 0.59 & 96 & 4.10 & $4.8 \times 10^{7}$ & 0.82 \\
\hline 20 & 4.32 & $1.9 \times 10^{7}$ & 0.60 & 120 & 3.90 & $2.9 \times 10^{7}$ & 0.89 \\
\hline 24 & 4.32 & $1.8 \times 10^{7}$ & 0.60 & ---- & ------ & ---- & ---- \\
\hline 28 & 3.98 & $1.1 \times 10^{7}$ & 0.89 & ------ & ------ & ----- & ----- \\
\hline
\end{tabular}

Table 6: Changes in $\mathrm{pH}$, total viable count and titratable acidity of the whey-pineapple $(65: 35)$ probiotic beverage during storage.

the days of storage of whey beverage both at refrigeration and room temperature.

\section{Total viable counts of probiotic beverage during storage}

The initial total viable count of the beverage was $3.8 \times 10^{7} \mathrm{cfu} /$ $\mathrm{ml}$ which decreased to $1.8 \times 10^{7}$ at refrigerated storage. Although the viability of Lactobacillus acidophilus population decreased, the viable count of the probiotic beverage did not fall below $10^{6} \mathrm{cfu} / \mathrm{ml}$ (Table 6). During storage at $30 \pm 1^{\circ} \mathrm{C}$, the total viable count first increased to $9.5 \times 10^{8}$ (in $48 \mathrm{hr}$ ) and then gradually declined to $2.9 \times 10^{7} \mathrm{cfu} / \mathrm{ml}$ after $120 \mathrm{hr}$. Our results are in confirmation with other researchers $[17,18]$ who also reported a decline in total viable count of Lactobacillus reuteri and Biofidobacterium bifidum of whey based probiotic beverage stored at $4 \pm 1^{\circ} \mathrm{C}$. Shah et al. [19], studied the survival of Lactobacillus acidophilus in commercial yoghurt during refrigerated storage.

\section{Conclusion}

Above study has revealed satisfactorily good quality probiotic beverage with therapeutic value prepared by using a $65: 35$ blend of whey and pineapple juice inoculated with 1 percent inoculum of Lactobacillus acidophilus with a shelf life of $24 \mathrm{~d}$ at $5 \pm 1^{\circ} \mathrm{C}$ and $48 \mathrm{hrs}$ at $30 \pm 1^{\circ} \mathrm{C}$.

\section{References}

1. Prendergast K (1985) Whey drink - technology, processing and marketing. Int J Dairy Technol 38: 103-105.

2. Singh S, Singh AK, Patil GR (2005) Whey utilization for health beverage. Indian Food Industry 21: 38-41.

3. Klaenhammer TR (1998) Functional activities of lactobacillus probiotics: Genetic mandate. Inter Dairy J 8: 497-507.

4. Gilliland SE (1990) Health and nutritional benefits from lactic acid bacteria. FEMS Microbiology Rev 87:175-188.

5. Williams S (1984) Official methods of analysis. $14^{\text {th }}$ edition. Association of Official Analytical Chemists, Washington D.C, USA
6. Ranganna S (1986) Handbook of analysis and quality control for fruit and vegetable products. $2^{\text {nd }}$ edition. Tata McGraw Hill Publishing Company Ltd. New Delhi, India

7. APHA, Vanderzant C (1992) Splits Toesser, ed. Compendium of methods for microbiological examination of foods. Washington. Amer Public Health Assoc 14: $919-927$

8. Elliker PR, Anderson AW, Hennenson G (1956) An Agar Culture Medium for Lactic Acid Streptococci and Lactobacilli. J Dairy Sci 39: 1611-1612.

9. Snedecor GW, Cochron WG (1977) Statistical methods. (6 $6^{\text {th }}$ Edn), Oxford and IBH Publishing Co, India.

10. Larmond E (1977) Laboratory methods for sensory evaluation of foods Department of Agriculture. Ottawa, Canada.

11. Tamine AY, Marshall VME, Robinson RK (1995) Microbiological and technological aspects of milks fermented by bifidobacteria. J Dairy Res 62 151-187.

12. Srivastava MK, Trimurtulu N, Lohani PP (1985) Utilization of by-products by Dairy Industries-Whey and Butter Milk. Ind Dairyman 37: 507-509.

13. Kumar RS, Manimegalai G (2003) A study on storage behavior of whey based pineapple juice RTS beverage. Ind Food Packer 7: 51-53.

14. Kumar RS, Manimegalai G (2002) A delicious soymilk, whey blended papaya RTS. Beverage and Food World 1: 42

15. Devi MSS, Banumathi P, Jothi N (2004) Studies on development and evaluation of whey based fruit beverages. Beverage and Food World 1: 44-46.

16. Reddy GJ, Rao BVR, Reddy KRS, Venkayya D (1987) Development of a Whey Beverage. Ind J Dairy Sci 40: 445-450.

17. Mendoza AH, Robles VJ, Angulo JO, Cruz JDL, Garcia HS (2007) Preparation of a whey based probiotic product with Lactobacillus reuterii and Bifidobacterium bifidus. Food Technol Biotechnol 45: 27-31.

18. Divya, Archana Kumari (2009) Effect of different temperatures, timings and storage periods on physico-chemical and nutritional characteristics of wheyguava beverage. World J Dairy Food Sci 4: 118-122.

19. Shah NP, Lankaputhra WEV, Britz ML, Kyle WAS (1995) Survival of Lactobacillus acidophilus and Bifidobacterium bifidum in commercial yoghurt during refr. 